Original Research Paper

\title{
Implementation of Species-Transport Model in Numerical Simulation to Predict the Performance of Downdraft Gasifier with Biomass Blends
}

\author{
${ }^{1}$ Murugan, P.C., ${ }^{2}$ G. Arun Prasad and ${ }^{3}$ S. Joseph Sekhar \\ ${ }^{1}$ Department of Mechanical Engineering, Kongu Engineering College, Erode, India \\ ${ }^{2}$ Department of Mechanical Engineering, St. Xavier's Catholic College of Engineering, Nagercoil, India \\ ${ }^{3}$ Department of Mechanical Engineering, Shinas College of Technology, Sultanate of Oman, Oman
}

\author{
Article history \\ Received: 30-08-2019 \\ Revised: 05-09-2019 \\ Accepted: 07-09-2019 \\ Corresponding Author: \\ Murugan, P.C. \\ Department of Mechanical \\ Engineering, Kongu \\ Engineering College, Erode, \\ India \\ Email: pcmurugan@ymail.com
}

\begin{abstract}
The demand for energy from biomass gasification is increasing due to the depletion of fossil fuels and serious environmental issues. Due to this, usage of individual biomass in a gasifier is not sufficient to meet the demand in rural areas. However, an enormous study have been reported on the gasifier with single biomass as working fuel. In addition, only a few works have been carried out on biomass blends in a gasifier through equilibrium modelling and experimental approach. The numerical simulation for the biomass blends are in scarce. Hence, in this study, a numerical and experimental studies were conducted on a $40 \mathrm{~kW}_{\text {th }}$ downdraft biomass gasifier to find out the possibility of rubber seed kernel shell and cassava stalk biomass with different blend ratio. The species-transport CFD model is used for numerical simulation with the k- $\varepsilon$ turbulence model. The effect of species concentration, higher heating value and conversion efficiency with respect to different equivalence ratio have been observed. The simulated results were also validated through experimentation. Among different blending ratio 80:20 blend shows better performance. The result reveals that the species concentration and higher heating value at 0.2 equivalence ratio has an average value of $\mathrm{CO}-23.5 \%, \mathrm{H}_{2}-19.2 \%, \mathrm{CH}_{4}-3.1 \%$ and $6.62 \mathrm{MJ} / \mathrm{Nm}^{3}$ with an efficiency of $58.23 \%$ respectively. The viability of using the species transport model for biomass blends is confirmed.
\end{abstract}

Keywords: Biomass, Gasifier, Cassava Stalk, Rubber Seed Kernel Shell, Species Concentration, Higher Heating Value

\section{Introduction}

The thermochemical conversion process is the most eco-friendly and economically viable route to convert the biomass into liquid or gaseous fuels (Guo et al., 2010) (Rao 2003). It is suggested that the thermochemical method is a good alternative to replace the direct burning of fuels in the future with high thermal efficiency with less $\mathrm{CO}_{2}$ emissions (Asadullah 2014) (Kirubakaran et al., 2009). The only obstacle that limits the large-scale applications on gasification conversion technology is the formation of tar but it is less significant when it is used for thermal applications. Moreover, 64\% of the households are using the firewood for cooking purpose and another $26 \%$ are using crop residue and animal waste (Bhattacharyya 2006). However, on a comparative study of household energy use pattern in India and China, it is reported that $80 \%$ of the solid fuels are used for direct burning of fuels in the residential sector (Pachauri and Jiang, 2008). Apart from the household applications, biomass is extensively used in various traditional and rural enterprises such as rice parboiling, hotels, restaurants and potteries (Kishore et al., 2004). Several experimental studies have been conducted on the downdraft biomass gasifier with furniture waste and wood chips (Zainal et al., 2001), wood waste (Sheth and Babu 2009), hazelnut shells (Olgun et al., 2011), corn straw (Gai et al., 2014), sawmill residues (Altafini et al., 2003), cashew nutshell (Singh et al., 2006), Jatropha seed husk (Vyas and Singh, 2007), peanut shell waste (Nisamaneenate et al., 2015) as feedstock. Equilibrium model analysis were also carried out for the feedstock such as wood, paddy husk and municipal waste (Zainal et al., 2002), beech chips (Schuster et al., 2001), sawdust (Altafini et al., 2003), corn stalks, sunflower stalks and rapeseed straw (Azzone et al., 2012), wood pellets (Di Blasi et al., 2013). Christus et al., (2014) used two-zone kinetic equilibrium models to predict 
the performance of the gasifier with different biomass blends available in rural areas. The achieved HHV of the producer gas was around $7.5 \mathrm{MJ} / \mathrm{Nm}^{3}$. The studies also indicate that the downdraft biomass gasifier has a significant variation in its performance whenever the feedstock is changed (Christus and Sekhar, 2016). It was suggested that equilibrium models are less computationally intensive and they cannot predict highly accurate results for all cases (Maria et al., 2010).

Martin et al. (2006) used a CFD model to optimize the combustion chamber for the solid baled biomass by distinguishing the air supply in the primary nozzle. The model helps to select the steel grade for the gasifier to prevent slagging and corrosion. Keran et al. (2013) studied the gasification of lignite for three position nozzle using the mixture fraction model and reported that the water gas shift reaction is in equilibrium throughout the reaction chamber. Skodras et al., (2003) worked out the simulation of molten slag gasification using CFD with appropriate user-defined subroutines. Because of the high temperature prevailing inside the molten bath gasifier, the heat exchange is fast and the flow field lies well inside the turbulent regime and also foaming slag occurs. Zhao et al. (2006) investigated the coal gasification technology using ASPEN PLUS. The effects of changes of oxygen, steam and natural gas on the co-gasification process were studied using the sensitivity analysis. This model lacks in fuel flexibility and availability of the gasifier by reconstructing a blast furnace. Luc et al. (2008) presented a 2D axisymmetric CFD model for the two-stage downdraft gasifier and investigated that the pyrolysis zone is crucial for tar cracking. It is also highlighted that tertiary tar is destroyed by combustions and the pyrolysis gas composition is significantly influencing the process (Sheth and Babu, 2009). Kumar et al. (2008) modeled the downdraft gasifier with wood as feedstock and the performance of throat angle, throat diameter was studied along with the effect of preheating air during the gasification. It has been found that the throat angle influences the conversion efficiency. Andrew et al. (2010) simulated the two-stage up-flow and single- stage downflow entrained gasifier using the DPM to determine the actual trajectories of coal particles, for separate density and size fraction of the gasifier flow field. Thanh et al. (2012) investigated the gas velocities in both the riser and the recycle chamber aeration in a bubbling fluidized bed gasifier using CFD by incorporating the multi-fluid Eulerian model with kinetic theory of granular flows. The results predict well for the solid circulation rate and the temperature distribution along the riser which is measured experimentally using the hot mode CFD simulation.

Deyong et al. (2012) carried out the simulation of biomass gasification using ASPEN Plus and FLUENT. Both the software packages are better in their simulation tool. The pyrolysis process is very difficult and more complex to simulate in FLUENT but using the Ryield block in ASPEN plus makes it easier. Neerav and Ghoniem
(2013) investigated the multiphase reacting flows using LES model and RANS model respectively. The simulation is carried out by taking the coal particles in the Langrangian approach and gaseous phase in the Eulerian approach. The result reveals that the LES model is more suitable for an unsteady flow which will affect the mining and particle dispersion and hence the char conversion efficiency of the gasification is affected. The particle distribution in the gasification zone is predicted more in the RANS model. Mohan and Srividhya (2013) studied the simulation of $20 \mathrm{~kW}$ downdraft gasifier by species transport phenomena. The simulation is carried out by varying the porosity and the velocity of the inlet air. It was suggested that at a porosity of 0.525 the maximum temperature is evenly distributed inside the gasifier. Furthermore, when the velocity above $9 \mathrm{~m} / \mathrm{s}$, the amount of unburnt fuel inside the gasifier is increased. Ravi et al. (2013) modeled the fluidized bed combustion and gasification through CFD package. The parameters like the behaviour of fuel during feeding, mining of fuel in dense bed, ash sintering, fuel characteristics, CRF and fragmentation of fuel in dense bed with CFD needs to be explored. Murugan and Sekhar (2017a) used species transport model to study the dimensional suitability of gasifier for different feedstock such as coconut shell, rubberwood, rice husk (Murugan and Sekhar, 2017b) and rubber seed kernel shell. A similar study has also been carried out by varying the nozzle angle and inclination of a gasifier and the results were validated with experimentation (Murugan and Sekhar (2017b). From the literature, it is observed that only a few works have been reported on the biomass blends for gasifier and numerical simulation through the species transport model is scarce. Hence, in this paper, a simulation is carried out on the biomass blends with rubber seed kernel shell and cassava stalk as feedstock. The parameters such as species concentration, higher heating value, and cold gas efficiency were studied. The results obtained from the numerical simulation is also validated through the experimental result. The results show that the biomass blends shows better performance and possibility of using the cassava stalk as feedstock is also proved.

\section{Species Transport Model}

The chemical reactions which take part in the gasification processes are solved by the mass, momentum, Energy Equation and reaction of individual species. The general type of the transport equation for each species is given as:

$\partial / \partial t\left(\rho Y_{i}\right)+\nabla \cdot\left(\rho v^{\rightarrow} Y_{i}\right)=\nabla \cdot J^{\rightarrow}+R_{i}$

$R_{i}$ is the net rate of production of species $i$ by gasification reaction. $J$ is the diffusion flux of species $i$ which causes concentration gradients.

Mass diffusion for laminar flows is given as: 


$$
J^{\rightarrow}=-\left(\rho D_{i, m}+\mu_{i} / S c_{i}\right) \nabla Y_{i}
$$

For turbulent flows, mass diffusion flux is given as:

$$
J^{\rightarrow}=-\rho D_{i, m} \nabla Y_{i}
$$

where, $D_{i, m}$ is the mass diffusion coefficient of species in the mixture and $S c_{i}$ is the turbulent Schmidt number.

So, the transport equations for each chemical species are:

$$
\begin{aligned}
& \frac{\partial}{\partial \mathrm{t}}\left(\rho Y_{C}\right)+\nabla\left(\rho \vec{v} Y_{C}\right)=-\nabla \cdot \vec{J}_{C}+R_{C} \\
& \frac{\partial}{\partial \mathrm{t}}\left(\rho Y_{O_{2}}\right)+\nabla\left(\rho \vec{v} Y_{O_{2}}\right)=-\nabla \cdot \vec{J}_{O_{2}}+R_{O_{2}} \\
& \frac{\partial}{\partial \mathrm{t}}\left(\rho Y_{\mathrm{CO}_{2}}\right)+\nabla\left(\rho \vec{v} Y_{\mathrm{CO}_{2}}\right)=-\nabla \cdot \vec{J}_{\mathrm{CO}_{2}}+R_{\mathrm{CO}_{2}} \\
& \frac{\partial}{\partial \mathrm{t}}\left(\rho Y_{C O}\right)+\nabla\left(\rho \vec{v} Y_{C O}\right)=-\nabla \cdot \vec{J}_{C O}+R_{C O} \\
& \frac{\partial}{\partial \mathrm{t}}\left(\rho Y_{N_{2}}\right)+\nabla\left(\rho \vec{v} Y_{N_{2}}\right)=-\nabla \cdot \vec{J}_{N_{2}}+R_{N_{2}} \\
& \frac{\partial}{\partial \mathrm{t}}\left(\rho Y_{H_{2}}\right)+\nabla\left(\rho \vec{v} Y_{H_{2}}\right)=-\nabla \cdot \vec{J}_{H_{2}}+R_{H_{2}} \\
& \frac{\partial}{\partial \mathrm{t}}\left(\rho Y_{\mathrm{CH}_{4}}\right)+\nabla\left(\rho \vec{v} Y_{\mathrm{CH}_{4}}\right)=-\nabla \cdot \overrightarrow{J_{\mathrm{CH}_{4}}}+R_{\mathrm{CH}_{4}} \\
& \frac{\partial}{\partial \mathrm{t}}\left(\rho Y_{\mathrm{H}_{2} \mathrm{O}}\right)+\nabla\left(\rho \vec{v} Y_{\mathrm{H}_{2} \mathrm{O}}\right)=-\nabla \cdot \overrightarrow{J_{\mathrm{H}_{2} \mathrm{O}}}+R_{\mathrm{H}_{2} \mathrm{O}} \\
& \frac{\partial}{\partial \mathrm{t}}\left(\rho Y_{\mathrm{H}_{2} \mathrm{O}(\mathrm{1})}\right)+\nabla\left(\rho \vec{v} Y_{\mathrm{H}_{2} \mathrm{O}(1)}\right)=-\nabla \cdot \overrightarrow{J_{H_{2} O(1)}}+R_{\mathrm{H}_{2} \mathrm{O}(1)}
\end{aligned}
$$

The net rate of production or destruction of species $i$ as the result of reaction $r, R_{i, r}$, is given by the smaller of the two expressions below:

$$
\begin{aligned}
& R_{i, r}=v_{i, r}^{\prime} M_{i, r} A \rho \frac{\varepsilon}{k} \min _{R}\left(\frac{Y_{r}}{v_{R, r}^{\prime} M_{w, j}}\right) \\
& R_{i, r}=v_{i, r}^{\prime} M_{i, r} B \rho \frac{\varepsilon}{k}\left(\frac{\sum_{p} Y_{p}}{\sum_{j}^{N} v_{j, r}^{\prime \prime} M_{w, j}}\right)
\end{aligned}
$$

where, $Y_{p}$ is the mass fraction of any product species, $P$, $Y_{r}$ is the mass fraction of a particular reactant, $R$.

\section{Modelling Procedure}

The schematic diagram of the biomass gasifier used in this study is shown in Fig. 1. The gasifier diameter and height is $640 \mathrm{~mm}$ and $2140 \mathrm{~mm}$ respectively and the diameter to height ratio is maintained as 0.30 . The throat diameter of the gasifier is $640 \mathrm{~mm}$ and the aspect ratio of the throat to the gasifier diameter is observed as 0.53 . The biomass inlet and gas outlet diameters are $400 \mathrm{~mm}$ and $340 \mathrm{~mm}$ respectively. The zones of the gasifier are placed at heights of $350 \mathrm{~mm}, 500 \mathrm{~mm}, 400 \mathrm{~mm}$ and 400 $\mathrm{mm}$ for the corresponding drying, pyrolysis, combustion and reduction zones respectively with a ratio of $2: 3: 2: 2$. The top of the gasifier is biomass inlet and defined as mass flow inlet and the gas outlet is defined as pressure outlet. The wall of the gasifier is considered as wall boundary with the no-slip condition. The ultimate and the proximate analyses of the feedstock used in this simulation are shown in Table 1 . It is very difficult to obtain a converged solution for a simulation which deals with combustion oriented eddy dissipation model. Therefore, a false time-stepping has been followed for the turbulence-chemistry interaction. The relaxation factor of 0.01 is used for the calculation of species concentration of producer gas. In order to reduce the complexity, only the outlet portion of the air nozzle is shown inside the gasifier. The inlet conditions of the biomass blends are given as listed in Table 2. The two- dimensional view of downdraft biomass gasifier is modeled in ANSYSDesign Modeler and exported to FLUENT for analysis. The assumptions such as the steady flow, no heat loss across the wall, homogenous property and chemical reactions are faster than turbulent eddies which have been considered to avoid the criticality. Since RNG k- $\varepsilon$ is robust, economic for computation and accurate for a wide range of turbulent flows, it has been selected to define the turbulence.

\section{Grid Independency Test}

Initially the domain was distributed into 15,000 coarse cells to check the grid independence and after the convergence, the compositions of $\mathrm{CO}$ and $\mathrm{H}_{2}$ were studied. Furthermore, to refine the cells to be fine, the number of cells was increased and the compositions of $\mathrm{CO}$ and $\mathrm{H}_{2}$ were studied and depicted in Fig. 2. The equivalence ratio was maintained at 0.30 during this research and the boundary conditions were maintained constant. The figure indicates that after the cell count is more than 150,000 , the structure of $\mathrm{CO}$ and $\mathrm{H}_{2}$ predicted from the research stays continuous. The same was therefore done for this assessment as the optimum (Andrew et al., 2010).

\section{Experimental Description}

The experimental setup comprises of a system for reactor and gas cleaning. The bunker at the top of the 
system feeds the biomass blends. The air required for the processes of gasification is sent via the air nozzle. With calibrated K-type (Chromel-Alumel) thermocouples, the temperatures within the gasifier for different zones are measured and recorded by the data logger. The composition of the producer gas is measured. A gas chromatograph (NUCON 5765) measures the composition of the producer gas. The gas samples are collected for different operating conditions in an airtight syringe and analyzed with argon as a carrier gas in the gas chromatograph.

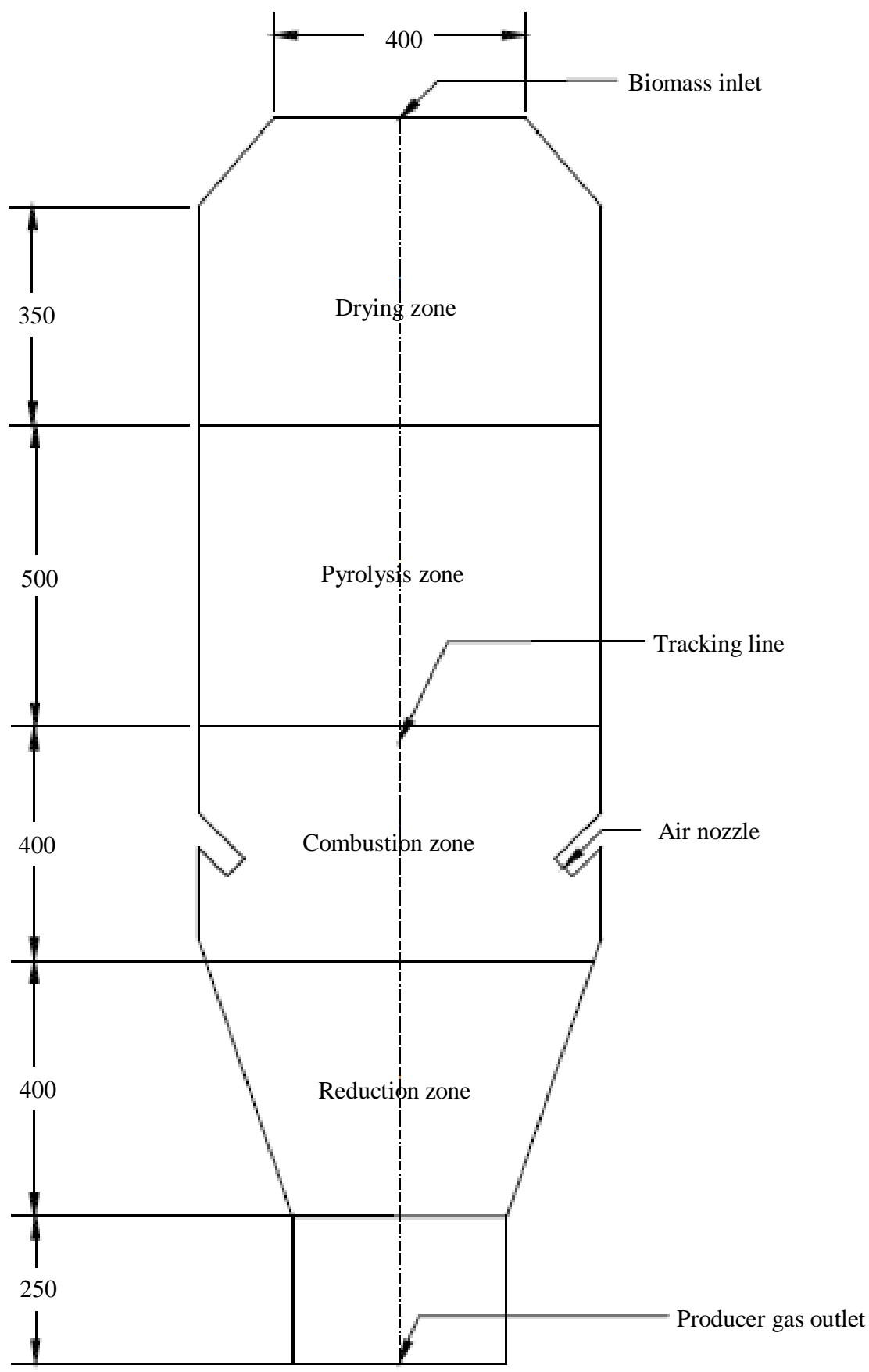

All dimesions are in $\mathrm{mm}$

Fig. 1: Description of the gasifier used for the simulation 
Murugan, P.C. et al. / Energy Research Journal 2019, Volume 10: 36.47 DOI: 10.3844/erjsp.2019.36.47

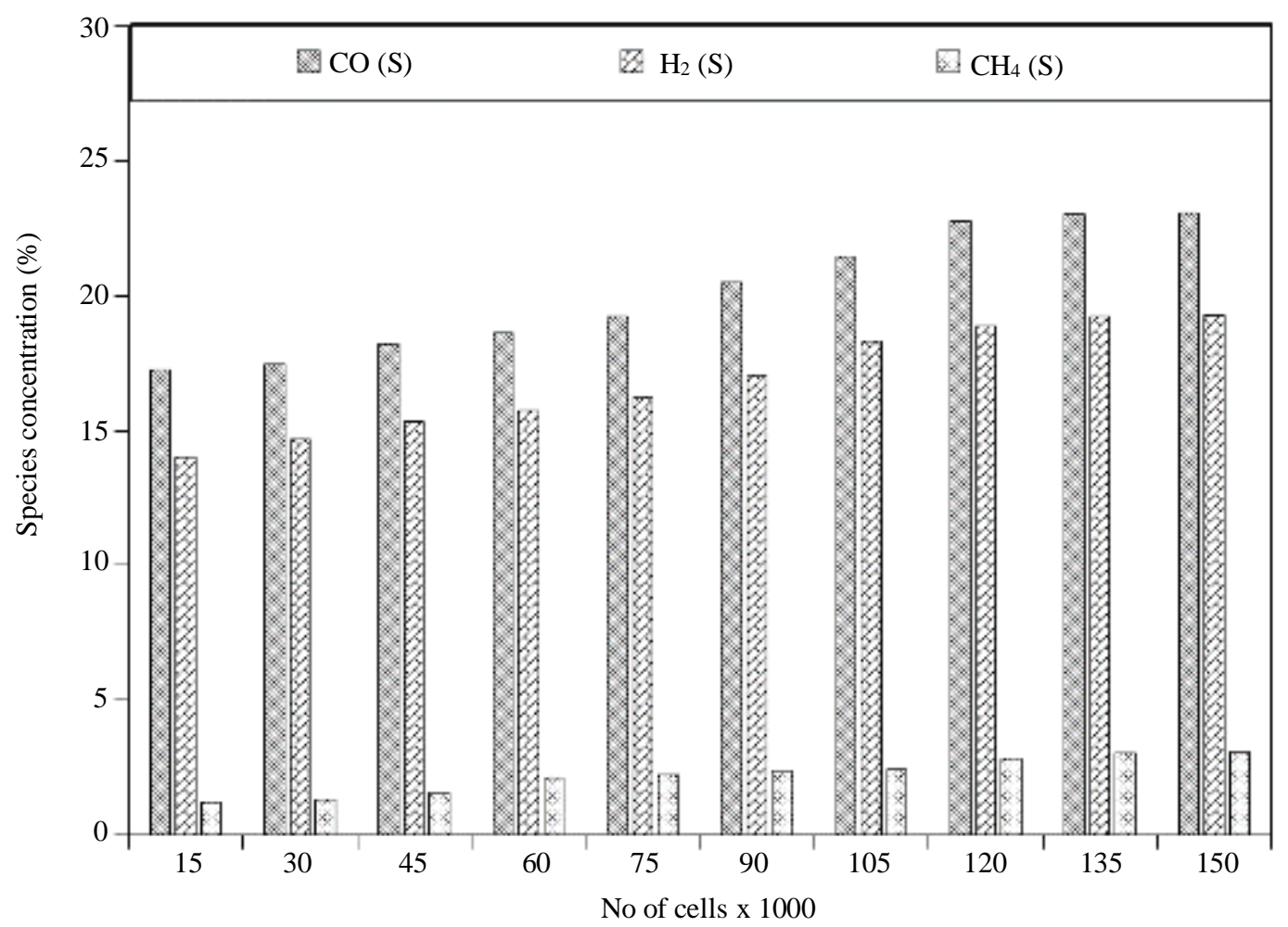

Fig. 2: Grid independency study

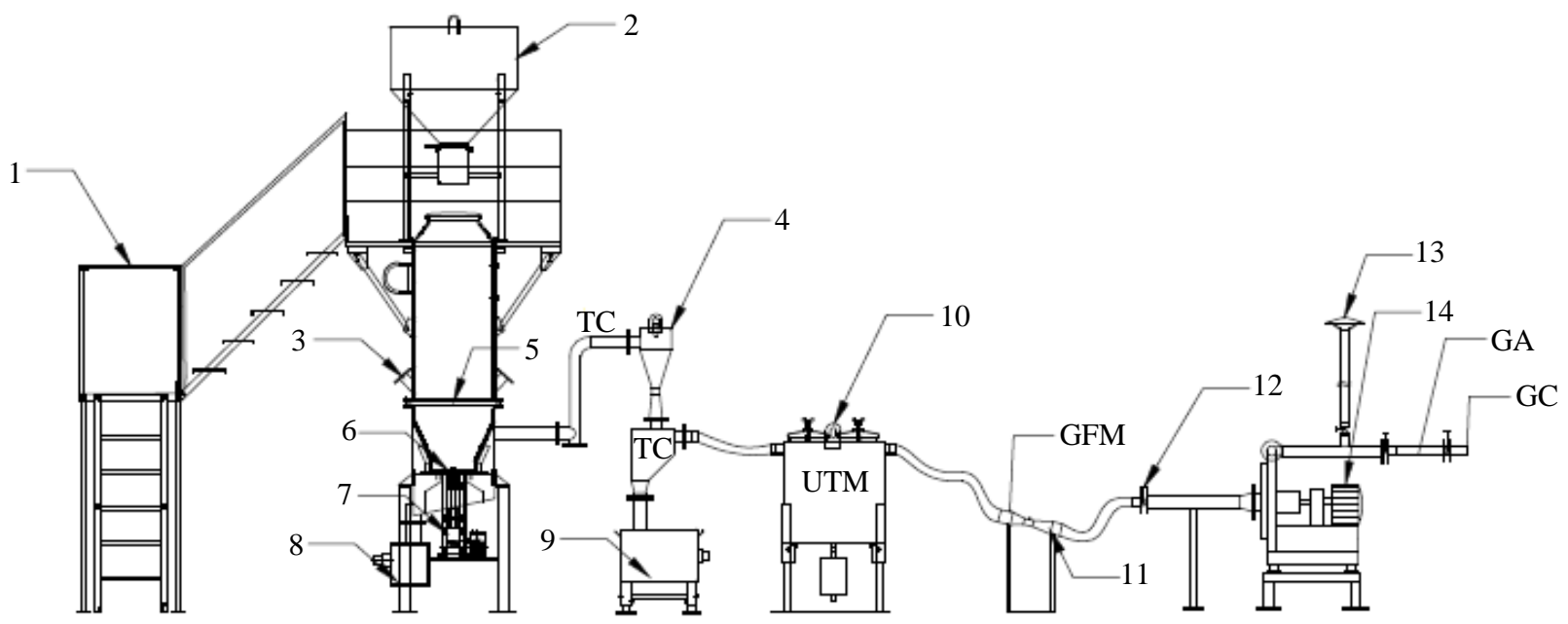

1. Ladder assembly for biomass feeding 2 . Bunker 3 . Air nozzle 4 . Ventura scrubber 5 . Combustion cone 6. Rotary grate

7. Gear box motor 8. Ash removal tub 9. Char removal tub 10. Coarse filter 11. Venturimeter 12. Gate valve

13. Flare 14. Centrifugal blower GC: Gas Chromatography UTM: U-Tube Manometer GA: Gas Analyzer GFM: Gas Flow Meter TC: K-type thermocouple

Fig. 3: Experimental setup of the downdraft biomass gasifier 
Murugan, P.C. et al. / Energy Research Journal 2019, Volume 10: 36.47 DOI: 10.3844/erjsp.2019.36.47

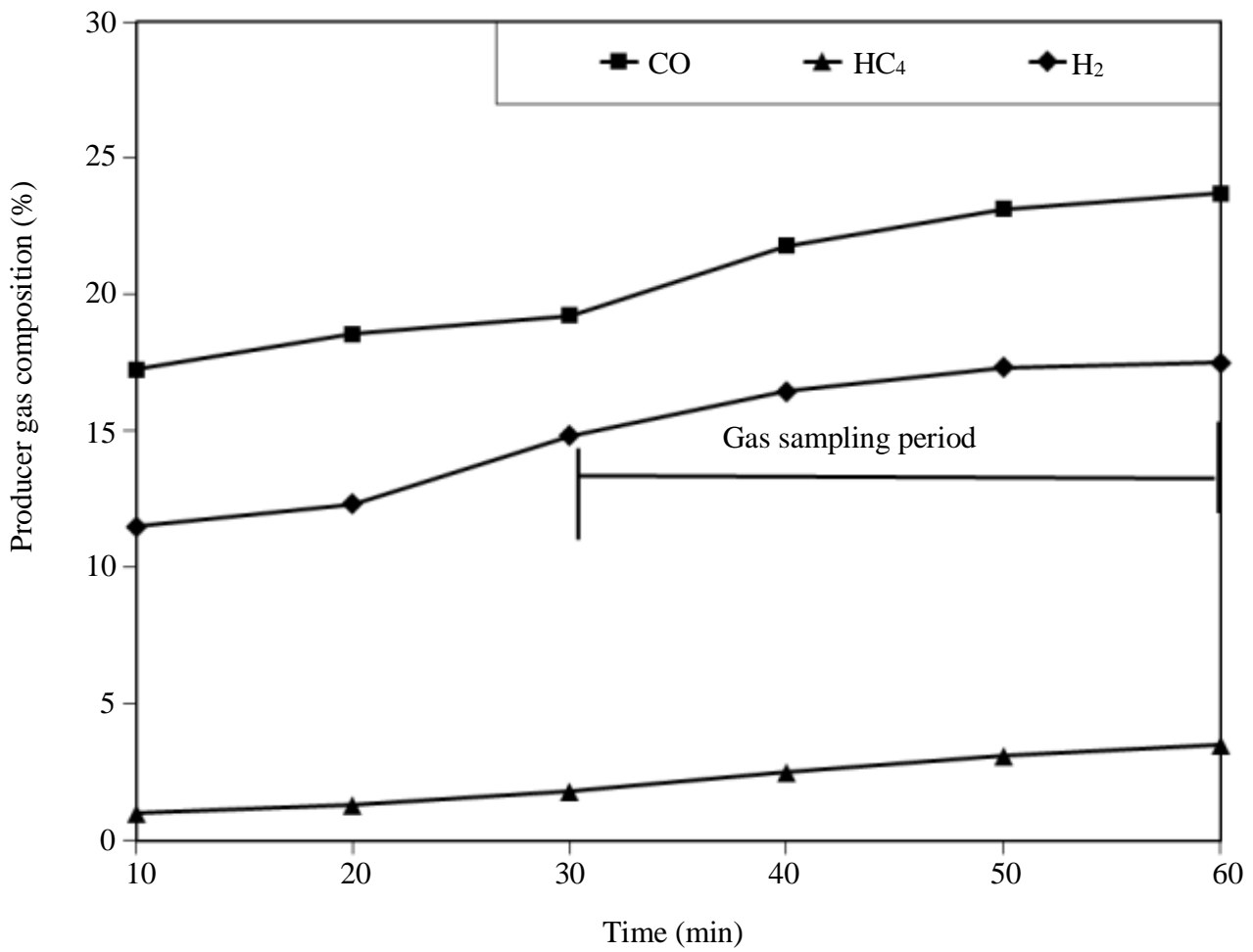

Fig. 4: Gas sampling period for $\mathrm{C} 2$ blend as feedstock in experimental study

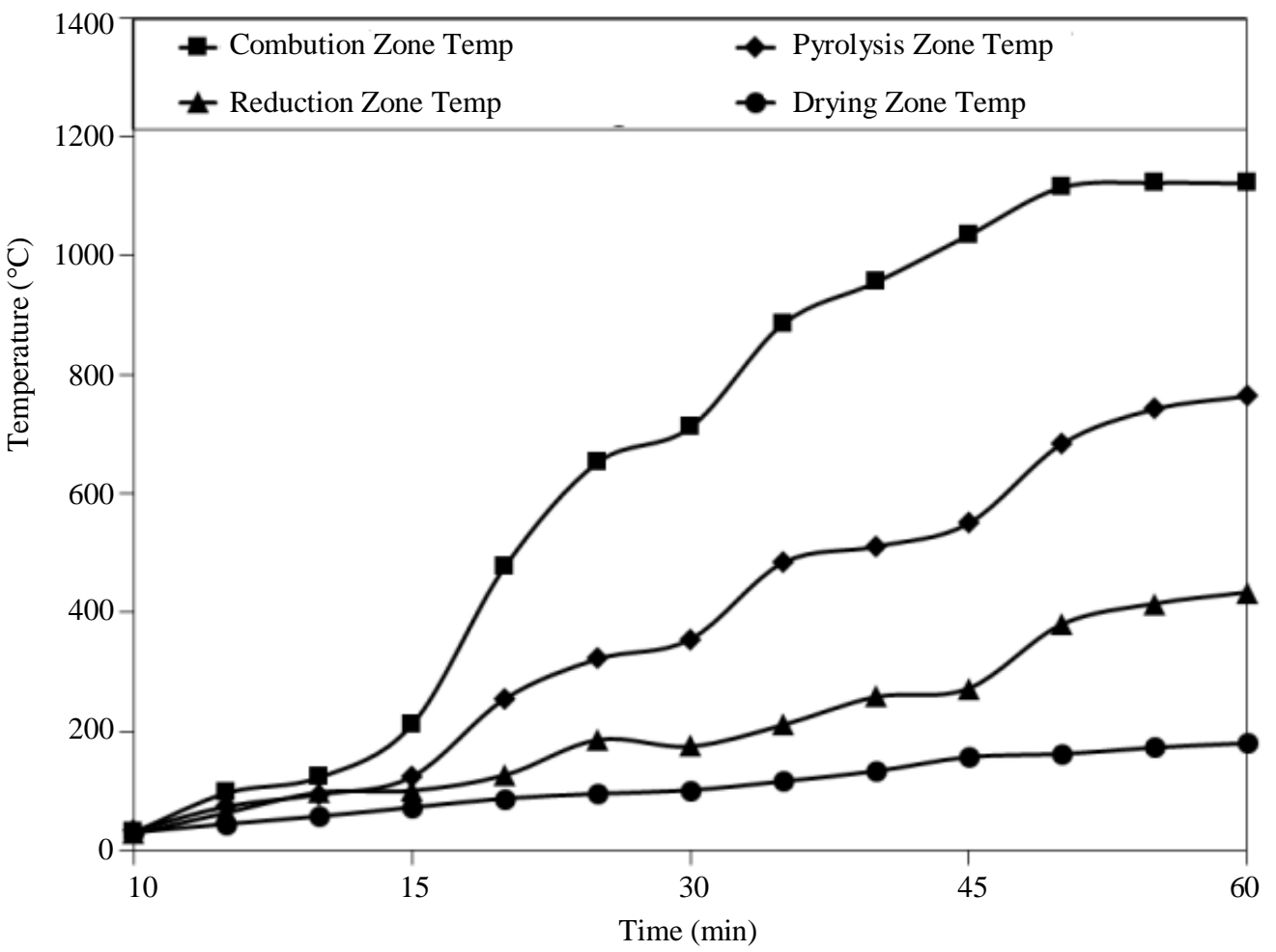

Fig. 5: Temperature distribution of the biomass gasifier 

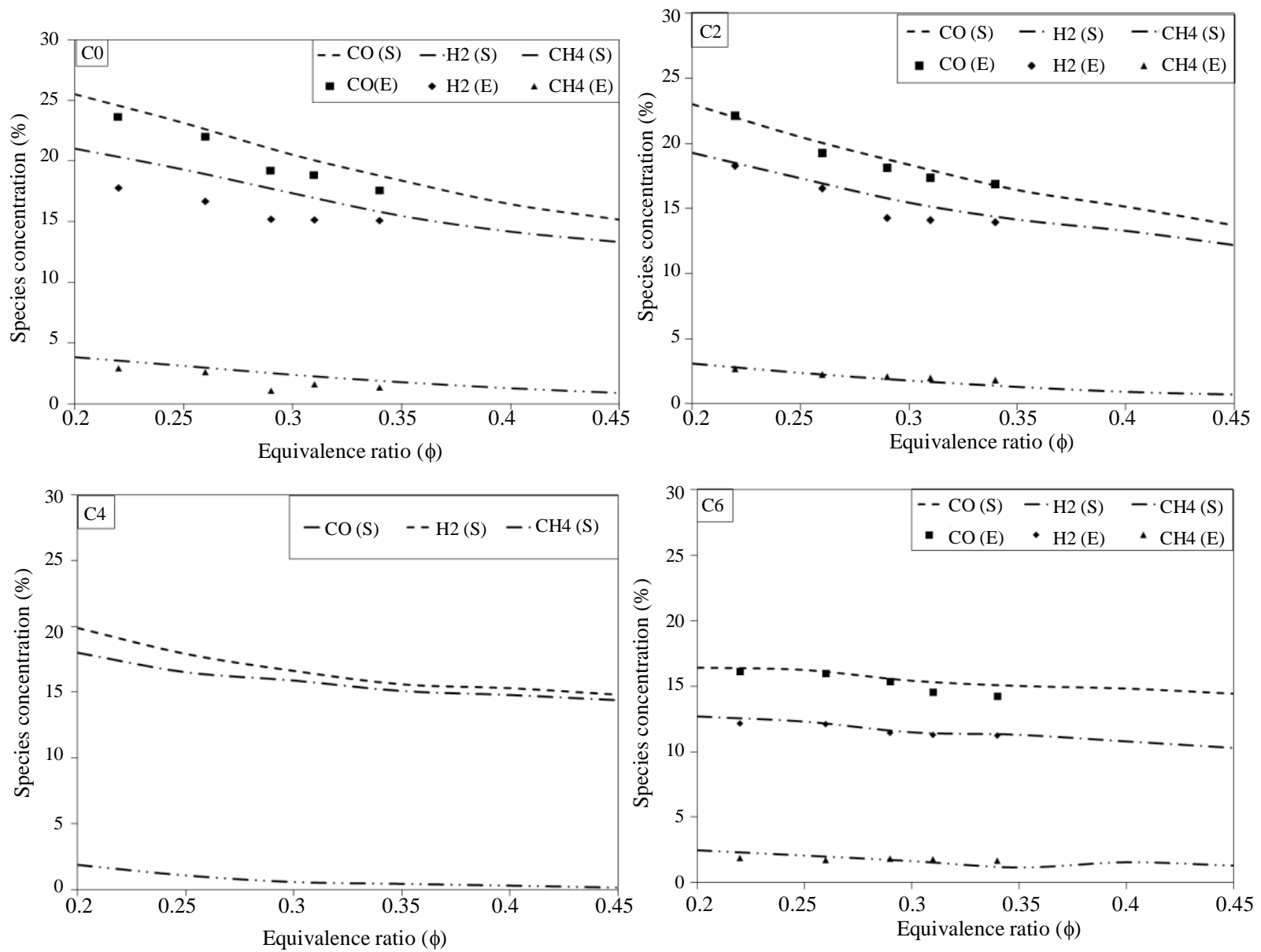

Fig. 6: Species concentration of producer gas obtained from different biomass blends

Table 1: Proximate and ultimate analysis of the feedstock used in this study

\begin{tabular}{|c|c|c|c|c|c|c|c|c|c|}
\hline \multirow[b]{2}{*}{ Feedstock } & \multicolumn{4}{|c|}{ Proximate Analysis (\% w.b.) } & \multicolumn{5}{|c|}{ Ultimate Analysis (\%) } \\
\hline & VM & $\mathrm{FC}$ & $\mathrm{MC}$ & Ash & $\mathrm{C}$ & $\mathrm{H}$ & $\mathrm{O}$ & $\mathrm{N}$ & S \\
\hline $\begin{array}{l}\text { Rubber seed } \\
\text { kernel shell }\end{array}$ & 89.4 & 6.1 & 4.3 & 0.2 & 43.2 & 6.0 & 0.55 & 50.25 & 0 \\
\hline Cassava stalk & 79.90 & 14.1 & 15.54 & 6.01 & 51.12 & 6.87 & 41.34 & 0.67 & - \\
\hline
\end{tabular}

Table 2: Different combination of blend used in this study

Feedstock combination

\begin{tabular}{|c|c|c|c|}
\hline Primary source & Secondary source & Blend ratio & Blend symbol \\
\hline \multirow{4}{*}{$\begin{array}{l}\text { Rubber seed kernel } \\
\text { shell }\end{array}$} & \multirow{4}{*}{ Cassava stalk } & $100: 0$ & $\mathrm{CO}$ \\
\hline & & $80: 20$ & $\mathrm{C} 2$ \\
\hline & & $60: 40$ & $\mathrm{C} 4$ \\
\hline & & $0: 100$ & C6 \\
\hline
\end{tabular}

\section{Experimental Procedure}

Initially, the wall of the gasifier was cleaned before loading the feedstock for the gasification process. The unit was then tested for leakage by sealing the biomass feed door and the combustion cone chamber with an insulation rope. The biomass blend was sun-dried to remove the excess moisture and to maintain the level to be less than $10 \%$. The biomass blends are loaded upto the level marked in the gasifier. The biomass blends are ignited using a small quantity of red- hot charcoal. The ash and char formed were collected by the water sprayer and it is passed to the water pond by a rotary grate which is driven by a special helical gearbox arrangement. 
Table 3: Mass balance of the gasifier for $\mathrm{C} 2$ blend as feedstock

\begin{tabular}{llllllll}
\hline & & \multicolumn{3}{c}{ Input } & & \multicolumn{2}{l}{ Output } \\
& $\begin{array}{l}\text { Equivalence } \\
\text { ratio }(\mathrm{ER})\end{array}$ & $\begin{array}{l}\text { Air flow rate } \\
\left(\mathrm{m}^{3} / \mathrm{h}\right)\end{array}$ & $\begin{array}{l}\text { Air flow rate } \\
(\mathrm{kg} / \mathrm{h})\end{array}$ & $\begin{array}{l}\text { Biomass consumption } \\
\text { rate }(\mathrm{kg} / \mathrm{h})\end{array}$ & $\begin{array}{l}\text { - } \\
\text { Producer gas } \\
\text { flow rate }(\mathrm{kg} / \mathrm{h})\end{array}$ & $\begin{array}{l}\text { Char } \\
\text { Collected }(\mathrm{kg} / \mathrm{h})\end{array}$ & $\begin{array}{l}\text { Mass } \\
\text { Balance }(\%)\end{array}$ \\
\hline 1. & 0.2 & 16.46 & 18.90 & 21.42 & 29.98 & 9.85 & 98.81 \\
2. & 0.25 & 17.32 & 19.65 & 22.56 & 31.42 & 9.62 & 97.24 \\
3 & 0.3 & 18.23 & 20.24 & 23.65 & 31.65 & 9.74 & 94.32 \\
4 & 0.35 & 19.83 & 22.84 & 24.47 & 34.91 & 10.42 & 95.82 \\
5 & 0.4 & 20.53 & 24.56 & 25.35 & 37.66 & 11.45 & 98.43 \\
\hline
\end{tabular}

The gas coming out from the gasifier is of high temperature $\left(>575^{\circ} \mathrm{C}\right)$ and is cooled by the water sprayer. The cooled gas is again sent to the coarse filter where the moisture content and other unwanted particles of the gas were removed. The gas starts coming out from the filter within $10 \mathrm{~min}$ from the start of the experimentation. The gas samples were taken after 10 minutes of the experimental run and the stabilization of the composition was observed after a period of $60 \mathrm{~min}$ and shown in Fig. 4. The temperature distribution of the gasifier for different zones are also noted and shown in Fig. 5. The experiment is carried out for the duration of $3 \mathrm{~h}$ and the average values of the producer gas composition, temperature distribution and higher heating value of the gas are noted. The consistency of the observed results are validated with the mass balance of the gasifier and are listed in Table 2. The water used for cleaning the gas is recycled using a pump. To measure the quantity of ash the water samples were collected during the start of operation and the tank is mixed well to avoid sedimentation at the bottom of the tank. The unburnt carbon and ash were calculated by the quantity of water in the tank and the variations in the density of the samples. The ash percentage calculated was between 5 to $6 \%$ and it is considered negligible. However, the residue collected from the sump is dried and utilized as fertilizer for gardening and agriculture.

\section{Results and Discussion}

The results from the numerical and experimental studies were examined and the parameters to evaluate the performance such as composition of producer gas, equivalence ratio, distribution of inside the gasifier for $\mathrm{C} 2$ blend as feedstock temperature and higher heating value were discussed. The numerical simulation used a tracking line as shown in Fig. 1 to track variations in the composition of the producer gas and other parameters.

\section{Species Concentration}

The producer gas composition observed from the numerical and experimental research for different biomass blends is plotted in Fig. 6(a-d). Although the numerical analysis was conducted for all the blends as shown in Table 3, only C2 is regarded for discussion with the experimental study of blend 80:20. It is observed that the recorded species concentration of the producer gas for rubber seed kernel shell as feedstock is stated as $23 \%, 18 \%$ and $3 \%$ for $\mathrm{CO}, \mathrm{H}_{2}$ and $\mathrm{CH}_{4}$ when the equivalence ratio is 0.2 . However, when the gasifier is operated with $100 \%$ non-mixed cassava stem, the concentration of the species is approximately $15 \% \mathrm{CO}$, $12 \% \mathrm{H}_{2}$ and $2 \% \mathrm{CH} 4$, which is found to be minimal for all cases. This could be due to the feedstock low energy content. Due to the existence of moisture content in the fuel, the endothermic reactions responsible for the gasification reactions has not took place efficiently in the C6 blend. It is also recognized from the figure that the mixing ratio of cassava stalk rises there is a substantial reduction in the concentration of the species with a rise in the equivalence ratio. Furthermore, the results show that there is close agreement between the species concentration from the numerical simulation and that of experimental observations for $\mathrm{C} 2$ with a 5 percent deviation that could be due to some assumptions taken in the research such as adiabatic wall without slip circumstances. This demonstrates the validity of the species transport model for the numerical simulation of various biomass blends.

\section{Higher Heating Value}

The individual rubber seed shell (C0) indicates a HHV of approximately $6.3 \mathrm{MJ} / \mathrm{Nm}^{3}$ when the equivalence ratio is 0.22 . From the Fig. 7, it is seen that the cassava stalk (C6) generates $5.4 \mathrm{MJ} / \mathrm{Nm}^{3}$ at equivalence ratio 0.22 . It is also noted that when the equivalence ratio is increased from 0.2 to 0.45 , the mixing of feedstock components drastically decreases the HHV. With regard to the $\mathrm{C} 2$ blend, the recorded $\mathrm{HHV}$ is $5.89 \mathrm{MJ} / \mathrm{Nm}^{3}$ owing to the high carbon content impact of the RSKS feedstock. The numerical simulation findings also show a comparable trend as the experimental study has acquired. The figure shows that there is a significant reduction in producer gas HHV when the equivalence ratio rises, which could be due to the greater $\mathrm{N}_{2}$ entry in the combustion area.

\section{Temperature Distribution}

Figure 8 shows the variation on the temperature distribution of $\mathrm{C} 2$ biomass blends. The temperature plays an important role within the gasifier for the effect of endothermic reactions. 


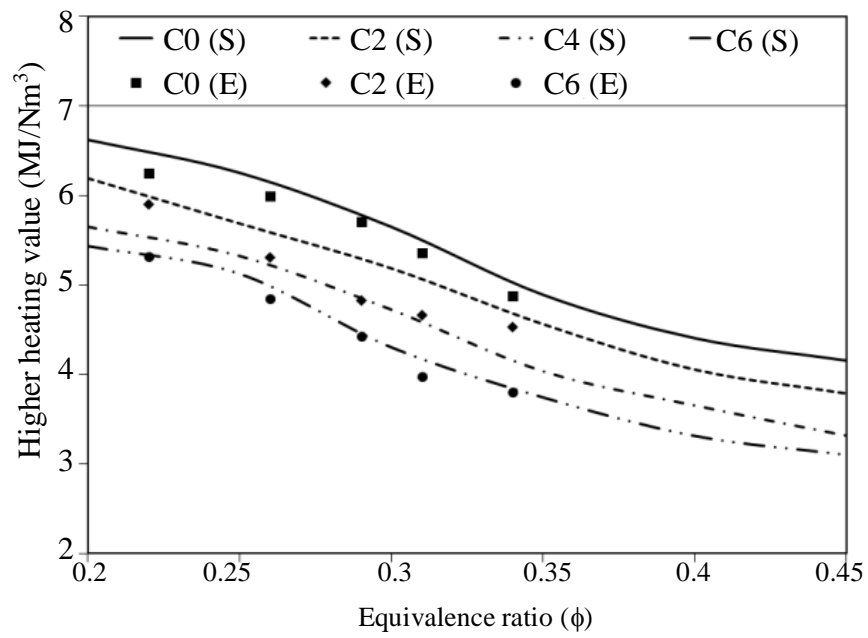

Fig. 7: Higher heating value of the producer for various biomass blends

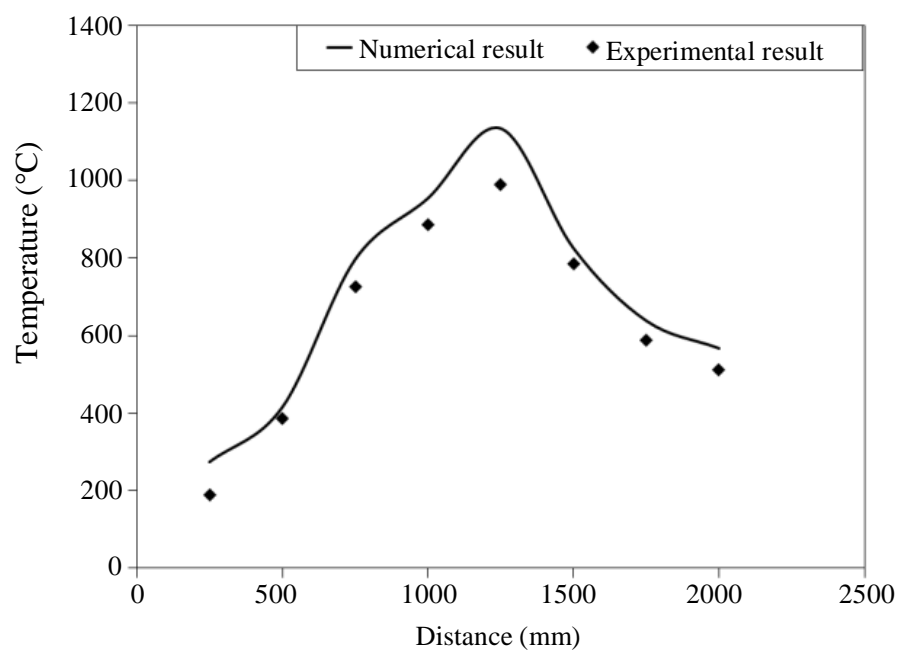

Fig. 8: Variation on the temperature distribution of $\mathrm{C} 2$ biomass blends

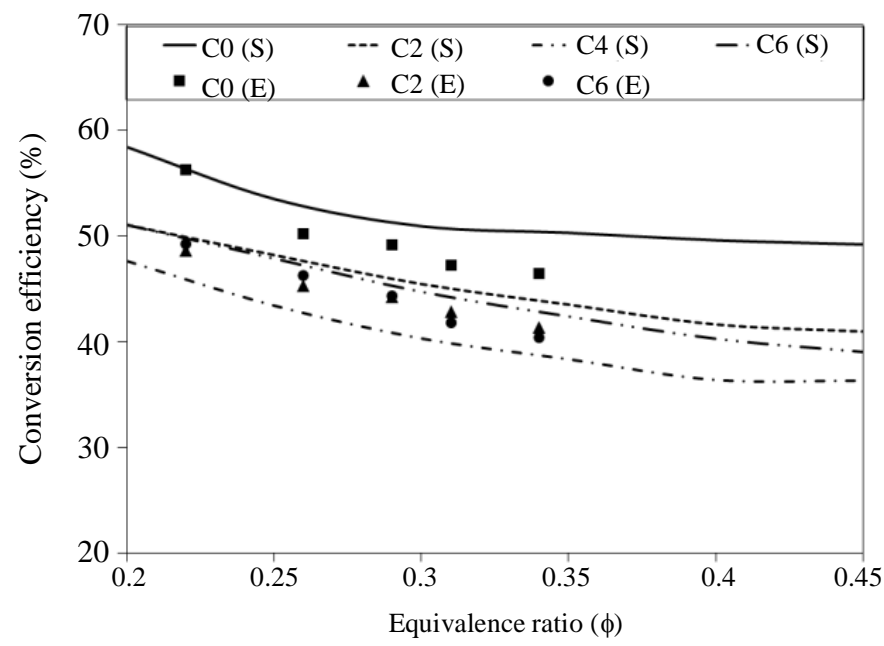

Fig. 9: Variation on the conversion efficiency for various biomass blends 
When low temperature is achieved, it is seen that the reactions inside the gasifier will not be completed and thus results the low producer gas composition. The studies show that the temperature of the gasifier observed from the numerical of $\mathrm{C} 2$ blend at various zones such as drying, pyrolysis, combustion and reduction zone are noted as 197 to $221^{\circ} \mathrm{C}, 434$ to $689^{\circ} \mathrm{C}, 997$ to $1123^{\circ} \mathrm{C}$ and 731 to $524^{\circ} \mathrm{C}$. The trend observed from the numerical and the experimental study is similar and the suitability of the proposed simulation is confirmed.

\section{Conversion Efficiency}

Figure 9 shows the variation on the conversion efficiency for various biomass blends. It is observed that the conversion efficiency is maximum when the biomass blend is rich in rubber seed kernel shell ranging from $57 \%$ to $54 \%$ for the equivalence ratio of 0.2 for the conditions tested. The conversion efficiency is fairly good for the equivalence ratio between 0.2 and 0.45 when rubber seed shell is blended with cassava stalk. For blend C2, the conversion efficiency is reported to be around $53 \%$ to $48 \%$, which may be due to insufficient heat required for endothermal reactions or excess fuel combustion. Similar trends are observed for all the tested conditions.

\section{Conclusion}

The numerical simulation the species transport model was carried out in a downdraft biomass gasifier with different biomass blends of rubber seed shell and cassava stalk as feedstock. The following findings are drawn based on the current research:

- The species concentration decreases with increase in the equivalence ratio from 0.2 to 0.45 and found to be maximum when rubber seed kernel shell is used as feedstock and the average value of species concentration for the $\mathrm{C} 2$ blend is reported to be $23 \%, 18 \%$ and $3 \%$ for $\mathrm{CO}, \mathrm{H}_{2}$ and $\mathrm{CH}_{4}$ respectively

- The HHV of producer gas for the C2 blend drastically decreases with increase in the equivalence ratio and it is maximum at 0.22 with $5.83 \mathrm{MJ} / \mathrm{Nm}^{3}$ and the trend for the conversion efficiency are similar to each other

- The deviation from the simulated outcomes and the experimental observations is between 5 and $10 \%$. The suggested model can therefore be used to forecast for any biomass blends in a downdraft gasifier

\section{Acknowledgement}

The authors would like to recognize St. Xavier's Catholic College of Engineering for providing permission to carry out the sponsored study project.

\section{Funding Information}

The authors would like to recognize, under reference no. 20/AICTE / RIFD / RPS/(POLICY- 1)17/2013-14, the "All India Technical Education Council (AICTE), India" to provide economic assistance through a sponsored study project

\section{Author's Contributions}

Murugan P C: Coordinated the numerical simualtion and contributed to the writing of the manuscript.

Arun Prasad G: Helped for carrying out the experimental work for this article.

Joseph Sekhar S: Supervised the research plan and organized the study

\section{Ethics}

This article is original and contains unpublished material. The corresponding author confirms that all of the other authors have read and approved the manuscript and no ethical issues involved.

\section{References}

Altafini, C.R., P.R. Wander and R.M. Barreto, 2003. Prediction of the working parameters of a wood waste gasifier through an equilibrium model. Energy Conversion Managem., 44: 2763-2777. DOI: $10.1016 / \mathrm{S} 0196-8904(03) 00025-6$

Andrew, S., J.M. Kuhlman, L.J. Shadle, J. Spenik and S. Shi, 2010. CFD simulation of entrained-flow coal gasification: Coal particle density/sizefraction effects. Powder Technol., 203: 98-108.

DOI: 10.1016/j.powtec.2010.03.029

Asadullah, M., 2014. Biomass gasification gas cleaning for downstream applications: A comparative critical review. Renewable Sustainable Energy Reviews, 40: 118-132. DOI: 10.1016/j.rser.2014.07.132

Azzone, E., M. Morini and M. Pinelli, 2012. Development of an equilibrium model for the simulation of thermochemical gasification and application to agricultural residues. Renewable Energy, 46: 248-254.

DOI: 10.1016/j.renene.2012.03.017

Bhattacharyya, S.C., 2006. Energy access problem of the poor in India: Is rural electrification a remedy?. Energy Policy, 34: 3387-3397. DOI: 10.1016/j.enpol.2005.08.026

Christus, V.J.S. and S.J. Sekhar, 2016. Performance studies on a downdraft biomass gasifier with blends of coconut shell and rubber seed shell as feedstock. Applied Thermal Eng., 97: 22-27.

DOI: 10.1016/j.applthermaleng.2015.09.099 
Christus, V.J.S., K. Thyagarajan, P. Murugan and S.J. Sekhar, 2014. Rubber seed kernel as a substitute for wood in a biomass gasifier-an experimental study. Advanced Materials Res.: Trans Tech Publ. DOI: 10.4028/www.scientific.net/AMR.984-985.845

Deyong, D., S. Li, W. Yang, J. Jia and N. Zheng, 2012. Application of numerical simulation on biomass gasification. Energy Procedia, 17: 49-54.

DOI: 10.1016/j.egypro.2012.02.061

Di Blasi, C. and C. Branca, 2012. Modeling a stratified downdraft wood gasifier with primary and secondary air entry. Fuel, 104: 847-860.

DOI: 10.1016/j.fuel.2012.10.014

Gai, C., Y. Dong and T. Zhang, 2014. Downdraft gasification of corn straw as a non-woody biomass: Effects of operating conditions on chlorides distribution. Energy, 71: 638-644.

DOI: 10.1016/j.energy.2014.05.009

Guo, Y., S. Wang, D. Xu, Y. Gong and H. Ma et al., 2010. Review of catalytic supercritical water gasification for hydrogen production from biomass. Renewable Sustainable Energy Reviews, 14: 334343. DOI: 10.1016/j.rser.2009.08.012

Keran, D.P., N. Shah and R. Patel, 2013. CFD Analysis of spatial distribution of various parameters in downdraft gasifier. Proc Eng., 51: 764-769.

DOI: 10.1016/j.proeng.2013.01.109

Kirubakaran, V., V. Sivaramakrishnan, R. Nalini, T. Sekar and M. Premalatha, et al., 2009. A review on gasification of biomass. Renewable Sustainable Energy Reviews, 13: 179-186.

DOI: 10.1016/j.rser.2007.07.001

Kishore, V., P.M. Bhandari and P. Gupta. 2004. Biomass energy technologies for rural infrastructure and village power-opportunities and challenges in the context of global climate change concerns. Energy Policy, 32: 801-810. DOI: 10.1016/S03014215(03)00002-8

Kumar, S.S., K. Pitchandi and E. Natarajan, 2008. Modeling and simulation of down draft wood gasifier. J. Applied Sci., 8: 271-279.

DOI: $10.3923 /$ jas.2008.271.279

Luc, G., M. Paraschiv, R. Vijeu, J. Bellettre and M. Tazerout et al., 2008. Numerical investigation of the partial oxidation in a two-stage downdraft gasifier. Fuel, 87: 1383-1393.

DOI: $10.1016 /$ j.fuel.2007.07.009

Maria, P.A., M., J.C. Bruno and A. Coronas, 2010. Review and analysis of biomass gasification models. Renewable Sustainable Energy Reviews, 14: 28412851. DOI: 10.1016/j.rser.2010.07.030

Martin, M., A. Makaruk, M. Harasek and A. Friedl, 2006. CFD- modelling for the combustion of solid baled biomass. Parameters.
Mohan, R.C. and P. Srividhya, 2013. CFD simulation of $20 \mathrm{~kW}$ downdraft gasifier. Current Eng. Technol., 3: 209-214

Murugan, P. and S.J. Sekhar, 2017a. Numerical simulation of imbert biomass gasifier to select the feedstock available in remote areas. Environ. Progress Sustainable Energy. 36: 708-716. DOI: 10.1002/ep.12485

Murugan, P. and S.J. Sekhar, 2017b. Numerical studies to predict the impact of air nozzle position and inclination on the performance of downdraft gratifier. J. Applied Fluid Mechanics, 10: 947-955.

Murugan, P. and S.J. Sekhar, 2017c. Species - Transport CFD model for the gasification of rice husk (Oryza Sativa) using downdraft gasifier. Comput. Electronics Agric., 139: 33-40. DOI: $10.1016 /$ j.compag.2017.05.004

Neerav, A and A.F. Ghoniem, 2013. Large eddy simulations of coal gasification in an entrained flow gasifier. Fuel, 104: 664-680. DOI: 10.1016/j.fuel.2012.06.006

Nisamaneenate, J., D. Atong, P. Sornkade and V. Sricharoenchaikul, 2015. Fuel gas production from peanut shell waste using a modular downdraft gasifier with the thermal integrated unit. Renewable energy, 79: 45-50.

DOI: 10.1016/j.renene.2014.09.046

Olgun, H., S. Ozdogan and G. Yinesor, 2011. Results with a bench scale downdraft biomass gasifier for agricultural and forestry residues. Biomass Bioenergy, 35: 572-80. DOI: $10.1016 /$ j.biombioe. 2010.10 .028

Pachauri, S. and L. Jiang, 2008. The household energy transition in India and China. Energy Policy, 36: 4022-4035. DOI: 10.1016/j.enpol.2008.06.016

Rao, S.G., 2003. Experiments and modelling studies of producer gas based spark-ignited reciprocating engines. Indian Institute Sci.

Ravi, I.S., R.I., A. Brink and M. Hupa, 2013. CFD modeling to study fluidized bed combustion and gasification. Applied Thermal Eng., 52: 585-614. DOI: 10.1016/j.applthermaleng.2012.12.017

Schuster, G., G. Löffler, K. Weigl and H. Hofbauer, 2001. Biomass steam gasification - an extensive parametric modeling study. Bioresource Technol., 77: 71-79. DOI: 10.1016/S0960-8524(00)00115-2

Sheth, P.N. and B. Babu, 2009. Experimental studies on producer gas generation from wood waste in a downdraft biomass gasifier. Bioresource Technol., 100: 3127-3133.

DOI: 10.1016/j.biortech.2009.01.024

Singh, R., U. Jena, J. Patel and A. Sharma, 2006. Feasibility study of cashew nut shells as an open core gasifier feedstock. Renewable Energy, 31: 481-487. DOI: $10.1016 /$ j.renene.2005.04.010 
Skodras, G., S. Kaldis, G. Sakellaropoulos, D. Sofialidis and O. Faltsi, 2003. Simulation of a molten bath gasifier by using a CFD code. Fuel, 82: 2033-2044. DOI: $10.1016 / \mathrm{S} 0016-2361(03) 00171-6$

Thanh, N.D., M.W. Seo, Y.I. Lim, B.H. Song and S.D. Kim, 2012. CFD simulation with experiments in a dual circulating fluidized bed gasifier. Comput. Chem. Eng., 36: 48-56.

DOI: $10.1016 /$ j.compchemeng.2011.07.005

Vyas, D. and R. Singh, 2007. Feasibility study of Jatropha seed husk as an open core gasifier feedstock. Renewable Energy, 32: 512-517. DOI: $10.1016 /$ j.renene.2006.06.006

Zainal, Z., A. Rifau, G. Quadir and K. Seetharamu, 2001. Experimental investigation of a downdraft biomass gasifier. Biomass Bioenergy, 23: 283-289.

DOI: $10.1016 / \mathrm{S} 0961-9534(02) 00059-4$
Zainal, Z., R. Ali, C. Lean and K. Seetharamu, 2001. Prediction of performance of a downdraft gasifier using equilibrium modeling for different biomass materials. Energy Conversion Management, 42: 1499-1515. DOI: 10.1016/S0196-8904(00)00078-9

Zhao, Y., W. Hao and X. Zhihong, 2006. Conceptual design and simulation study of a co-gasification Technology. Energy Conversion Management, 47: 1416-1428.

DOI: 10.1016/j.enconman.2005.08.024 